\title{
Small montane cloud forest fragments are important for conserving tree diversity in the Ecuadorian Andes
}

\author{
Sarah Jane Wilson ${ }^{1,3}$, and Jeanine M. Rhemtulla ${ }^{2}$ iD \\ ${ }^{1}$ School of Natural Resources and Environment, University of Michigan, 440 Church St, Ann Arbor, MI 48109, USA \\ ${ }^{2}$ Department of Forest and Conservation Sciences, University of British Columbia, 2424 Main Mall, Vancouver, BC V6T 1Z4, Canada
}

\begin{abstract}
Montane tropical cloud forests, with their complex topography, biodiversity, high numbers of endemic species, and rapid rates of clearing, are a top global conservation priority. However, species distributions at local and landscape scales in cloud forests are still poorly understood, in part because few regions have been surveyed. Empirical work has focused on species distributions along elevation gradients, but spatial variation among forests at the same elevation is less commonly investigated. In this study, the first to compare tree communities across multiple Andean cloud forests at similar elevations, we surveyed trees in five ridge-top forest reserves at the upper end of the 'mid-elevation diversity bulge' (1900-2250 masl) in the Intag Valley, a heavily deforested region in the Ecuadorian Andes. We found that tree communities were distinct in reserves located as close as 10 to $35 \mathrm{~km}$ apart, and that spatially closer forests were not more similar to one another. Although larger (1500 to $6880 \mathrm{ha}$ ), more intact forests contained significantly more tree species (108-120 species/0.1 ha) than smaller (30 to $780 \mathrm{ha}$ ) ones (56-87 species/0.1 ha), each reserve had unique combinations of more common species, and contained high proportions of species not found in the others. Results thus suggest that protecting multiple cloud forest patches within this narrow elevational band is essential to conserve landscape-level tree diversity, and that even small forest reserves contribute significantly to biodiversity conservation. These findings can be applied to create management plans to conserve and restore cloud forests in the Andes and tropical montane cloud forests elsewhere.
\end{abstract}

Abstract in Spanish is available with online material.

Key words: andean biogeography; conservation planning; mid-elevation diversity bulge; single large or several small; tropical mountain forest.

Tropical mONTANE Cloud FORESTS REMAin a TOP GLOBAL CONSERVATION PRIORITY. Restricted to areas frequently engulfed in clouds, they are among the most species rich forests in the world (Gentry et al. 1995, Myers et al. 2000, Bruijnzeel 2004, Brooks et al. 2006). Andean cloud forests in particular are hotspots of biodiversity and endemism: over 15 percent of known plant species, including five percent of endemic plant species, are found in the tropical Andes in less than one percent of the earth's land area (Mittermeier et al. 1999, Zador et al., 2015). Although stand-level species richness (alpha-diversity) is often lower in cloud forest than lowland forest, landscape-level species richness (beta-diversity) is typically higher in cloud forest due to the high number of endemic species (Noss 1983, Haber 2000, Küper et al. 2004).

How to best conserve this species diversity has long been a topic of debate. The 'single large or several small' (SLOSS) literature, for example, has debated the merits of protecting a single large tract versus several smaller patches of habitat in fragmented landscapes (Diamond, 1975, Picket \& Thompson 1978, Simberloff \& Abele 1982, Margules \& Pressey 2000, Lindenmayer \& Fischer, 2006). The 'single large' approach prioritizes

Received 22 June 2017; revision accepted 11 December 2017.

${ }^{3}$ Corresponding author; e-mail: sjwil@umich.edu. areas large enough to allow biodiversity to persist in isolation (Diamond 1975, Schwartzman et al. 2000); but while this approach will likely increase the persistence of some species, it may also capture a smaller amount of the overall regional diversity (Simberloff \& Abele 1982, Ovaskainen 2002). Which approach is better seems highly case specific and depends in large part on the degree of overlap in species composition between fragments on the landscape (Patterson 1987, Tjorve 2010). Understanding underlying patterns of species distribution and the factors associated with them is therefore important for designing protected areas.

In this study, we examine cloud forest tree species distributions within a small elevational belt in Andean Ecuador to inform present and future conservation actions. Historically, Andean cloud forests occupied approximately $60,000 \mathrm{~km}^{2}$ (Mulligan 2010), but to date, more than half have been cleared. Although rates have slowed in the past decade, clearing continues today (Mulligan 2010, Scatena et al. 2010, Aide et al. 2013). Remaining forests are often in fragmented patches within a matrix of other land uses (Young et al. 1995, Jokisch \& Lair 2002, WilliamsLinera 2002, Echeverría et al. 2007, Scatena et al. 2010). Moreover, montane cloud forest is typically dissected by mountain peaks and valleys, and patches are thus geographically isolated from one another and tend to show a high degree of species 
variation in space (Wilson 1992, Fjeldså et al. 1999, Sarmiento 2002, Legendre et al. 2005, Young 2009).

Where cloud forests remain, using scientific data to prioritize which stands to conserve is limited by a lack of species inventories and knowledge of how species are distributed across the landscape (Bruijnzeel et al. 2010). Most empirical, field-based studies in montane forests have focused on species turnover along elevational gradients, which is high in both Andean (Jankowski et al. 2013, Salazar et al. 2013, Myster 2017) and non-Andean cloud forests (Givnish 1998, Lomolino et al. 2001, Sanchez-Gonzalez \& Lopez-Mata 2005, Cardelus et al. 2006, Williams-Linera et al. 2013). Fewer studies have compared tree communities within the same elevational belt, although studies in montane cloud forests in China, the Columbian Andes, and Peru suggest that tree communities vary considerably at the same elevation, with marked differences based on slope, aspect, and substrate type (Howard 1968, Sugden 1982, Aiba \& Kitayama 1999, Shi \& Zhu 2009). Few other studies compare cloud forests within an elevational belt, with none, to our knowledge, in Ecuador.

Empirical studies quantifying how cloud forest patches contribute to conserving tree diversity at the landscape scale suggest that protecting forests at a range of different elevations is critical to conserving biodiversity (Gentry 1988, Williams-Linera et al. 2013). But how best to select conservation sites so as to conserve biodiversity also depends on species distribution between forests at similar elevations. The purpose of this study was therefore to characterize: (1) variability in the diversity and species composition of trees, and (2) environmental variation among five cloud forest sites within the same narrow elevational belt (1900-2250 $\mathrm{m}$ asl) in northwest Andean Ecuador.

\section{METHODS}

STUDY SITE.-We surveyed primary cloud forests in five reserves in the Intag region (Imbabura and Pichincha provinces, $0^{\circ} 21^{\prime} 0^{\prime \prime} \mathrm{N}$, $78^{\circ} 30^{\prime} 0^{\prime \prime} \mathrm{W}$, Table 1) in Andean Ecuador. Intag is rugged and steep, with an average annual temperature of $17-20^{\circ} \mathrm{C}$, annual rainfall ranging from 1500 to $3300 \mathrm{~mm}$, and a single pronounced dry season from May/June to October (Freiberg \& Freiberg 2000). As in many Andean cloud forest regions, most low-to-mid elevation primary cloud forests (1000-2300 m asl) have been cleared (Sarmiento 1995, Armenteras et al. 2003) and remnant patches are separated by ridges and agricultural fields (Wilson 2015). Although protected under various arrangements, several of our sites face significant conservation challenges, including illegal logging at the margins, settlement encroachment, and the threat of mining exploration. Mid-elevation forests in the Andes are a high conservation priority as they have been heavily cleared in many places, may be under high threat of future clearing (this elevation is suitable for both agriculture and pasture), and encompass the upper end of the 'mid elevation biodiversity bulge', associated with high species turnover and species richness (Gentry et al. 1995).

Located within a relatively small $\left(875 \mathrm{~km}^{2}\right)$ geographic area, the five study reserves ranged from 30 ha (Nangulvi) to 6880 ha (Los Cedros) (Table 1, Fig. 1). The larger reserves were situated in larger patches of forest connected at higher elevations, and thus reserve size was generally indicative of patch size. Each reserve occupied a ridge separated by valleys or ridges of over $400 \mathrm{~m}$ higher than other study reserves. In the portion of the reserves where we conducted our study, none had been cleared in living memory; human use has been limited to rustic ecotourism and non-invasive research for at least the past 15 years, with no signs of recent logging or harvesting activities (i.e., stumps, clearings, cut branches).

TABLE 1. Description of the five primary forest reserves studied in the Intag Valley, Ecuador.

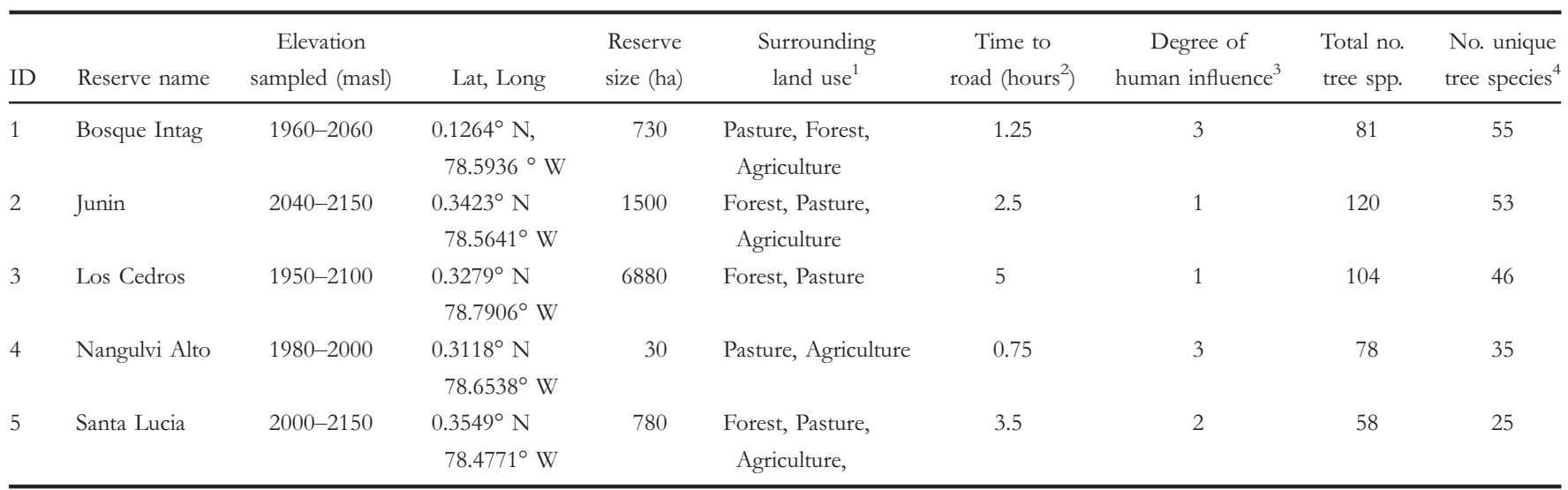

${ }^{1}$ Main uses found at the perimeter of the reserve. 'Forest' indicates that the reserve is connected to another reserve. The order of the land uses corresponds to the relative amount of each surrounding each reserve.

${ }^{2}$ Approximate time to walk from the area sampled to the nearest car-passable road.

${ }^{3}$ Degree of human influence is a ranking based on interviews with long-term residents and landowners. $1=$ sites have not been used in the past; $2=$ reserves that were potentially used by people but use was either minimal or ceased more than 10 years ago; 3 = reserves located near working agricultural landscapes that may sustain light human activity.

${ }^{4}$ Number of tree species unique to the reserve (not found in other reserves). 


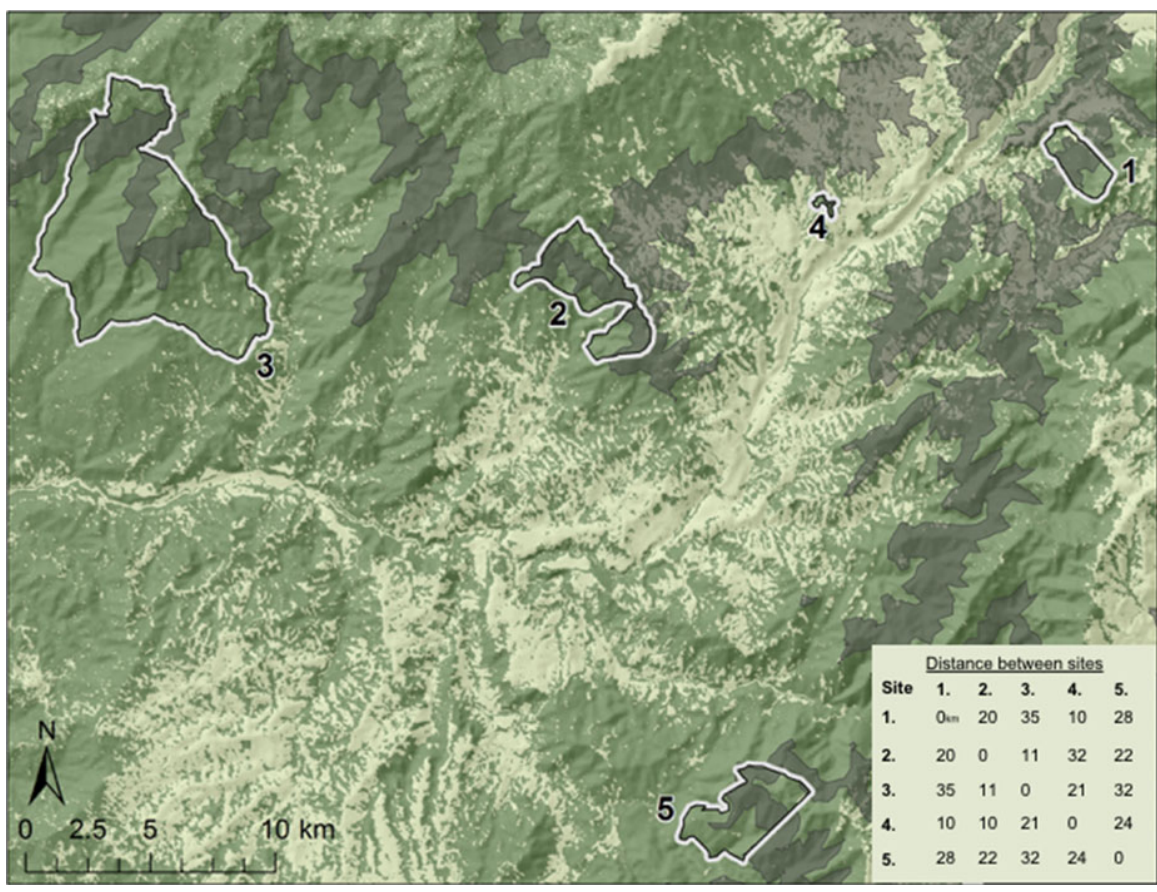

FIGURE 1. Map of primary forest reserves studied. Distance between sites (in kilometers) is indicated in the table. Reserves are numbered alphabetically: 1 = Bosque Intag, $2=$ Junin, $3=$ Los Cedros, $4=$ Nangulvi, $5=$ Santa Lucia. Dark green $=$ tree cover, light green $=$ cleared areas, dark grey $=$ elevations between 1900 and 2250 masl. Note that tree cover is based on the Hansen dataset (Hansen et al. 2013) and indicates other trees besides primary forest cover (including plantations, agroforests, fallows, and young secondary forest).

Data collection.- - In each reserve, we surveyed trees along four $50 \mathrm{~m} \times 5 \mathrm{~m}$ transects (total $0.1 \mathrm{ha} /$ reserve). Transects were randomly placed in intact primary forest at least $100 \mathrm{~m}$ apart, perpendicular to the slope near ridgetops, over a range of slopes between $15-35^{\circ}$ and 1900-2250 masl (Table 1); spatial distribution of transects was comparable among all reserves despite differences in reserve size. Each transect was divided into five $5 \times 10 \mathrm{~m}$ plots in which we counted, identified, and measured trees $(>2.5 \mathrm{~cm}$ diameter-at-breast-height, dbh), woody saplings $(1-2.5 \mathrm{~cm} \mathrm{dbh})$ and seedlings $(>0.5 \mathrm{~m}$ height and $<1 \mathrm{~cm} \mathrm{dbh})$. Trees were identified to species in the field, and we took two replicate voucher samples, including reproductive parts when available, of unknown species and preserved them in 75-80 percent alcohol for identification by botanists at the Museo Ecuatoriano de Ciencias Naturales Herbario Nacional del Ecuador (QCNE). Vouchers that contained unique additions (e.g., flowers or seeds not in the QCNE collection) were donated to the herbarium. We counted plants as separate individuals when the stem of the plant was not connected at, or just below, the soil surface (Chazdon et al. 1998). At two random locations on each transect, we recorded elevation (Garmin GPS Map 60 unit), slope (analog clinometer), aspect (hand-held compass), canopy density (convex spherical densiometer; Lemmon 1957), and percent ground cover (estimated visually in two $1 \mathrm{~m}^{2}$ plots).

We collected composite samples of the top $10 \mathrm{~cm}$ of soil, mixing 10 samples taken at random along each transect. Composite samples were stored in a conventional refrigerator and delivered to the soil laboratory within 5 days (Estacion Experimental 'Santa Catalina', Instituto Nacional Autonomo de Investigaciones Agropecuarias, Cutuglagua, Mejía, Pichincha) where they were analyzed for: nitrogen $\left(\mathrm{NH}_{4}\right)$, phosphorus (Olson-modified), potassium, calcium, magnesium; bases; organic matter content; and soil texture. We measured bulk density by taking one sample per transect with a 10 by $10-\mathrm{cm}$ diameter cylindrical sampler. We weighed each sample while wet and after sun drying for up to 4 weeks in a hot attic until the dry weight had stabilized.

All reserves were under strict conservation, but because some were historically more accessible we quantified the degree of past human influence using two indicators: (1) travel time by foot to the nearest road; and (2) a ranking of the likely intensity of past access or extraction determined by interviewing landowners and long-time residents. We also surveyed for signs of human disturbance (e.g., stumps and cut branches) and found none.

Data analysis. - We quantified tree species richness using three indicators: (1) Rarefied species richness (resampling 100 times), which was compared between sites by calculating the $95 \%$ confidence intervals (Chazdon et al. 1998) and using ANOVA on species richness rarefied to a common number of stems (data were natural $\log$ transformed to meet assumptions of normality) (EstimateS version 8.2.0, Colwell 2009, SPSS IMB corp. 2011, v. 20.0); (2) Rarefied species density (species per hectare); and (3) the Chao richness estimator (Chao1), which was compared between sites to help correct for potential under-sampling bias (common in 
very biodiverse environments) (Chao 1984, Chen et al. 1995, Phillips et al. 2003).

We quantified differences between tree communities in reserves at the species, genus, and family levels using two indicators: (1) the Chao estimator of shared species, which estimates the number of shared species in each reserve (Chen et al. 1995); and, (2) the Chao-Jaccard similarity estimator, a measure of beta-diversity ranging from 0 (completely distinct communities) to 1 (identical communities). Both metrics correct for under-sampling bias by estimating the number of 'unseen' shared species between sites (Chao et al. 2005). We used non-metric multidimensional scaling (NMDS) ordination with the Chao-Jaccard similarity index (which accounts for potential undersampling bias) to visualize differences in tree communities within and between reserves (Fig. S2). For descriptive purposes only, we used redundancy analysis (RDA) (combined with variance partitioning) to examine correlations with the following spatial and environmental variables (Legendre et al. 2005): soil characteristics affecting plant growth (macronutrients, exchangeable bases, organic matter, and bulk density); site environmental data (slope and elevation); and landscape data (accessibility and size of reserve). When subsets of soil variables were correlated, we used a summary metric. For variance partitioning, we categorized variables into spatial (latitude, longitude), environmental (slope, aspect, elevation, soils), human disturbance (distance to road), and reserve size. NMDS ordinations were performed in PCord Version 6 (McCune \& Mefford 2011), and $\mathrm{RDA}$ and variance partitioning in the vegan package in $\mathrm{R}$ (Oksanen 2011).

\section{RESULTS}

Tree communities.-We identified 3296 stems from 302 species of woody plants in the five forest reserves (of these, 44 were identified to genus, and three, which we eliminated from analysis, only to family) (Fig. S1). The majority were trees (229 species) and woody shrubs (41), with tree ferns (10), canopy palms (5), and other woody plants of unknown form (17). Lianas were excluded from the dataset. For simplicity, from hereon we refer to all species as trees (Norden et al. 2009). Species belonged to 132 genera and 65 families, with the main tree families-Rubiaceae and Lauraceae-being typical of Andean cloud forests (Gentry et al. 1995).

Only one species, the most abundant (13\% of all stems), was found in all five reserves: Palicourea demisea, Rubiaceae (Table 2, Fig. S2). Other subcanopy trees in the family Rubiaceae were also widespread (i.e., in three or four reserves) and abundant (more than $1 \%$ of the total abundance of stems): Psychotria hazenii $(2.9 \%$ of total stems), Palicourea thyrsiffora (2.6\%), and Faramea calyptrate $(1.6 \%)$. Widespread, abundant canopy tree species included Billia rosea (1.4\%, Sapindaceae) and Weinmannia balbisiana $(1.3 \%$, Cunoniaceae). The most abundant canopy tree species, Carapa guianensis (Meliaceae) (3\%), was found only in one reserve (Junin). Other canopy tree species that were locally abundant in one or two reserves included Ossaea micrantha (2.6\%,
Melastomataceae), Calyptranthes maxima (1.8\%, Myrtaceae), and Ocotea stuebelii (1.2\%, Lauraceae) (Table 2, Fig. S2).

TREe SPECIES DENSITY AND RICHNESS.-Species richness and density ranged from 58 to 120 tree species per 0.1 ha. The most species dense, Junin $(120 / 0.1 \mathrm{ha})$, had more than twice the species per unit area than the least (Santa Lucia, 58/0.1 ha). Larger reserves (Junin and Los Cedros, 104/0.1 ha) contained the most species, followed by Bosque Intag (81/0.1 ha), with Santa Lucia and Nangulvi (78/0.1 ha) supporting fewer. Although the two largest reserves had the most species, the effect of size is not consistent: Nangulvi had more species than Santa Lucia, which is nearly 20 times larger in size (Fig. 2).

Rarefied species richness (to 480 stems) ranged from 58 to 94 species per reserve (Fig. 2). The most species rich reserve, Junin, had 1.6 times more species (90 species) than the least, Santa Lucia (58 species). The Chao 1 richness estimator showed even greater differences in species richness, with Junin (258 species) estimated to have nearly four times the species richness of Santa Lucia (81 species). Beta diversity - the dissimilarity between transects within each reserve- was consistent across reserves, with the exception of Nangulvi, which had lower beta diversity than the other reserves (analysis not shown). Overall, the species richness rank for each reserve remained the same regardless of the metric (rarefaction curves, rarefied richness, or the Chao index) used (Figs 2 and S1). Both rarefaction curves and the Chao index suggest that sampling was not comprehensive; despite this, there were clear and consistent differences in species richness between reserves.

Tree species Composition and shared taXa.-Each reserve supported distinct tree communities (Table 3, Figs S2 and S3). At the species level, even the most similar reserves shared fewer than 50 percent of species (Table 3A). The two most dissimilar reserves (Bosque Intag and Santa Lucia) shared only five species-an almost complete turnover in species composition over only $28 \mathrm{~km}$. The Chao-Jaccard similarity index ranged from 0.10 (almost completely distinct communities) to 0.53 between different reserves (Table 3A). Often, a given species common ( $>5$ specimens found) at one reserve was entirely absent from the others (Table 2). Turnover in genera was not as high as species turnover. Individual reserves housed 49 to 78 genera. Each reserve contained unique genera (e.g., even Santa Lucia, with the fewest genera, contained four unique genera), and the most dissimilar reserves still shared an estimated 19 genera. The Chao-Jaccard similarity index for genera ranged from 0.36 to 0.75 (Table 3B).

Generally, genera followed the same patterns as species across sites in terms of relative similarity. Variation at the family level was considerably lower than at the genera or species level. Each reserve housed between 29 and 40 families, with the most dissimilar reserves sharing an estimated 19 families. The ChaoJaccard similarity index for families ranged from 0.95 (almost identical communities) to 0.75 between different reserves (Table 3C). 
TABLE 2. Common species at each site, arranged by their frequency in the dataset. Numbers are the numbers of individuals found at each site. 'Common species' are defined as those where at least five individuals were found in a given reserve.

\begin{tabular}{|c|c|c|c|c|c|c|}
\hline \multirow[b]{2}{*}{ Species } & \multicolumn{5}{|c|}{ Site } & \multirow[b]{2}{*}{ Total } \\
\hline & 1-BI & $2-\mathrm{JN}$ & 3-LC & 4-NA & $5-\mathrm{SL}$ & \\
\hline Palicourea demissa & 59 & 106 & 89 & 129 & 47 & 430 \\
\hline Carapa guianensis & - & 107 & - & - & - & 107 \\
\hline Psychotria aff. hazenii & 1 & 2 & 83 & 12 & - & 98 \\
\hline Ossaea micrantha & - & - & 1 & 67 & 16 & 84 \\
\hline Palicourea thyrsiffora & - & 1 & 18 & 65 & - & 84 \\
\hline Castilla elastica subsp. gummifera & - & - & - & - & 62 & 62 \\
\hline Calyptranthes maxima & - & - & 32 & 27 & - & 59 \\
\hline Faramea calyptrata & - & 27 & 1 & - & 24 & 52 \\
\hline Urera baccifera & 47 & - & - & - & - & 47 \\
\hline Billia rosea & - & 27 & 6 & - & 13 & 46 \\
\hline Palicourea sodiroi & - & 6 & - & - & 40 & 46 \\
\hline Besleria solanoides & - & 3 & 13 & - & 29 & 45 \\
\hline Weinmannia balbisiana & - & 7 & 20 & 1 & 14 & 42 \\
\hline Psychotria setifera & 39 & - & - & - & - & 39 \\
\hline Geonoma undata & - & 17 & 21 & - & - & 38 \\
\hline Hyeronyma macrocarpa & 8 & - & - & 23 & 7 & 38 \\
\hline Ocotea stuebelii & - & 5 & 33 & - & - & 38 \\
\hline Cyathea pallescens & - & 6 & 28 & 2 & - & 36 \\
\hline Myrcia splendens & - & 20 & - & 16 & - & 36 \\
\hline Cestrum megalophyllum & - & 5 & 1 & 10 & 19 & 35 \\
\hline Meliosma occidentalis & - & 3 & - & 31 & - & 34 \\
\hline Palicourea cbignul & 34 & - & - & - & - & 34 \\
\hline Stylogyne ambigua & - & 12 & 1 & - & 20 & 33 \\
\hline Beilschmiedia costaricensis & - & 4 & 2 & 25 & 1 & 32 \\
\hline Citronella aff. incarum & - & 32 & - & - & - & 32 \\
\hline Prestoea acuminata & - & 18 & 3 & - & 11 & 32 \\
\hline Faramea langlassei & - & 29 & 2 & - & - & 31 \\
\hline Elaeagia mariae & - & - & - & 30 & - & 30 \\
\hline Meriania tomentosa & 7 & - & 15 & - & 8 & 30 \\
\hline Cyathea tortuosa & 18 & 10 & - & 1 & - & 29 \\
\hline Hedyosmum cuatrecazanum & 5 & - & - & 24 & - & 29 \\
\hline Miconia theaezans & 16 & 1 & 1 & - & 10 & 28 \\
\hline Acalppha diversifolia & - & - & - & 27 & - & 27 \\
\hline Faramea oblongifolia & 21 & - & - & - & 6 & 27 \\
\hline Gordonia fruticosa & - & - & - & 27 & - & 27 \\
\hline Machaerium sp.1 & - & 26 & - & - & - & 26 \\
\hline Nectandra purpurea & - & 10 & 15 & 1 & - & 26 \\
\hline Axinaea macrophylla & - & 25 & - & - & - & 25 \\
\hline Chrysocblamys colombiana & - & 2 & 4 & 11 & 8 & 25 \\
\hline Piper obtusilimbum & - & 10 & - & 15 & - & 25 \\
\hline Psammisia sodiroi & - & - & 25 & - & - & 25 \\
\hline Beilschmiedia tovarensis & - & 17 & 4 & - & 2 & 23 \\
\hline Inga densiftora & - & - & - & 23 & - & 23 \\
\hline Miconia crocea & 22 & - & - & - & - & 22 \\
\hline
\end{tabular}

TABLE 2 (continued)

\begin{tabular}{|c|c|c|c|c|c|c|}
\hline \multirow[b]{2}{*}{ Species } & \multicolumn{5}{|c|}{ Site } & \multirow[b]{2}{*}{ Total } \\
\hline & 1-BI & 2-JN & 3-LC & 4-NA & 5-SL & \\
\hline Casearia silvestris & - & 1 & 5 & 15 & - & 21 \\
\hline Guarea kunthiana & - & 4 & 2 & 11 & 3 & 20 \\
\hline Psychotria allenii & - & - & - & - & 20 & 20 \\
\hline Calatola costaricensis & - & 16 & - & - & 3 & 19 \\
\hline Delostoma integrifolium & - & - & - & 18 & - & 18 \\
\hline Critoniopsis occidentalis & - & 11 & 3 & - & 3 & 17 \\
\hline Ficus cuatrecasana & - & 4 & 3 & - & 10 & 17 \\
\hline Alchornea triplinervia & - & 6 & - & - & 10 & 16 \\
\hline Myrcia aff. fallax & - & 1 & 6 & - & 9 & 16 \\
\hline Naucleopsis capirensis & - & 16 & - & - & - & 16 \\
\hline Ocotea sp. 1 & - & 15 & - & - & - & 15 \\
\hline Persea nubigena & - & - & 15 & - & - & 15 \\
\hline Posoqueria coriacea & - & 5 & 3 & - & 7 & 15 \\
\hline Aiphanes chiribogensis & - & 6 & 7 & - & 1 & 14 \\
\hline Bertiera guianensis & - & - & 14 & - & - & 14 \\
\hline Cyathea caracasana & - & - & - & - & 14 & 14 \\
\hline Leandra longicoma & - & - & 14 & - & - & 14 \\
\hline Stephanopodium angulatum & - & 12 & 2 & - & - & 14 \\
\hline Piper auritum & 13 & - & - & - & - & 13 \\
\hline Stylogyne venezuelana & - & - & 12 & 1 & - & 13 \\
\hline Ardisia websteri & 2 & 4 & 5 & 1 & - & 12 \\
\hline Eschweilera of. integrifolia & - & 12 & - & - & - & 12 \\
\hline Eugenia grossa & 9 & 1 & - & 2 & - & 12 \\
\hline Inga sp.1 & - & - & 6 & 6 & - & 12 \\
\hline Nectandra sp.1 & - & - & - & 12 & - & 12 \\
\hline Piper hispidum & - & - & - & 12 & - & 12 \\
\hline Siparuna aspera & - & - & - & 12 & - & 12 \\
\hline Persea aff. americana & 11 & - & - & - & - & 11 \\
\hline Psycbotria capitata & 6 & 4 & - & 1 & - & 11 \\
\hline Tabernaemontana sp. & - & - & 11 & - & - & 11 \\
\hline Tetrorchidium macrophyllum & 4 & - & - & 2 & 5 & 11 \\
\hline Alchornea glandulosa & 10 & - & - & - & - & 10 \\
\hline Ceroxylon alpinum & 10 & - & - & - & - & 10 \\
\hline Ficus citrifolia & - & - & 10 & - & - & 10 \\
\hline Geissanthus sp. 2 & - & - & - & 10 & - & 10 \\
\hline Inga lallensis & - & 10 & - & - & - & 10 \\
\hline Miconia bracteolata & 2 & - & 8 & - & - & 10 \\
\hline Nectandra acutifolia & - & - & - & 10 & - & 10 \\
\hline Pseudolmedia rigida & 10 & - & - & - & - & 10 \\
\hline Sorocea jaramilloi & - & 10 & - & - & - & 10 \\
\hline Alchornea latifolia & 9 & - & - & - & - & 9 \\
\hline Axinaea sp.1 & - & - & 9 & - & - & 9 \\
\hline Clusia alata & 6 & - & 2 & - & - & 8 \\
\hline Eugenia crassimarginata & - & 8 & - & - & - & 8 \\
\hline $\begin{array}{l}\text { Hedyosmum goudotianum var. } \\
\text { goudotianum }\end{array}$ & - & - & 7 & 1 & - & 8 \\
\hline Myrcia macrophylla & - & - & - & - & 8 & 8 \\
\hline
\end{tabular}

(continued) 
TABLE 2 (continued)

\begin{tabular}{|c|c|c|c|c|c|c|}
\hline \multirow[b]{2}{*}{ Species } & \multicolumn{5}{|c|}{ Site } & \multirow[b]{2}{*}{ Total } \\
\hline & 1-BI & $2-\mathrm{JN}$ & 3-LC & $4-\mathrm{NA}$ & $5-\mathrm{SL}$ & \\
\hline Prunus debilis & - & - & - & - & 8 & 8 \\
\hline Siparuna aspera & - & 7 & 1 & - & - & 8 \\
\hline Turpinia occidentalis & - & - & 1 & 5 & 2 & 8 \\
\hline Daphnopsis zamorensis & - & 7 & - & - & - & 7 \\
\hline Myrsine andina & - & 5 & - & 2 & - & 7 \\
\hline Ocotea sericea & 7 & - & - & - & - & 7 \\
\hline Persea areolatocostae & - & 2 & 5 & - & - & 7 \\
\hline Ruagea tomentosa & - & - & - & 7 & - & 7 \\
\hline Thelypteris sp.1 & - & 5 & 2 & - & - & 7 \\
\hline Alsophila sp.2 & - & 6 & - & - & - & 6 \\
\hline Barnadesia parviflora & 6 & - & - & - & - & 6 \\
\hline Eschweilera caudiculata & - & - & - & - & 6 & 6 \\
\hline Licania macrocarpa & - & - & 6 & - & - & 6 \\
\hline Licania megalophylla & - & 6 & - & - & - & 6 \\
\hline Myrcianthes hallii & 6 & - & - & - & - & 6 \\
\hline Nectandra sp .4 & - & 6 & - & - & - & 6 \\
\hline Ossaea robusta & - & - & - & - & 6 & 6 \\
\hline Persea rigens & - & 6 & - & - & - & 6 \\
\hline Solanum dolosum & - & - & - & 6 & - & 6 \\
\hline Solanum lepidotum & - & - & - & 6 & - & 6 \\
\hline Clidemia sp. 2 & - & 5 & - & - & - & 5 \\
\hline Geissanthus andinus & 5 & - & - & - & - & 5 \\
\hline Geissanthus sp. 1 & - & 5 & - & - & - & 5 \\
\hline Mauria beteropbylla & - & - & - & 5 & - & 5 \\
\hline Nectandra sp. 2 & - & - & - & 5 & - & 5 \\
\hline Piptocoma discolor & 5 & - & - & - & - & 5 \\
\hline Solanum barbulatum & 5 & - & - & - & - & 5 \\
\hline Solanum stenophyllum & 5 & - & - & - & - & 5 \\
\hline
\end{tabular}

Although each reserve supported distinct tree communities, NMDS ordination revealed high correlations between several species (Fig. S2). The trees that showed high correlations were not necessarily the most abundant; rather, they were both unique to the reserve(s) they characterized and typically present in large numbers where they were found. Species associated with Bosque Intag were the canopy tree Alchornea latifolia (Euphorbiaceae), the endangered palm Ceroxylon alpinum (Arecaceae), and the subcanopy trees Hieronyma macrocarpa (Phyllanthaceae) and Miconia crocea (Melastomataceae). Sixty-eight percent of the species in this reserve were not found in any other reserve; when 'unseen' species were estimated, Bosque Intag shared at most 20 species with any other individual reserve (Table 3A). Reserves Nangulvi and, to a lesser extent, Los Cedros, were characterized by the canopy trees Inga densiflora (Fabaceae) and Casearia silvestris (Salicaceae), and the subcanopy tree Palicourea thyrsiflora (Rubiaceae). Although similar species characterized these two reserves, they shared only 23 species, and each contained distinct subsets of common species (Table 2). Santa Lucia and Junin, which shared 24 species, were characterized by the canopy trees Weinmannia balbisiana (Cunoniaceae), Stylogyne ambigua (Primulaceae), and the subcanopy tree Faramea calyptrate (Rubiaceae).

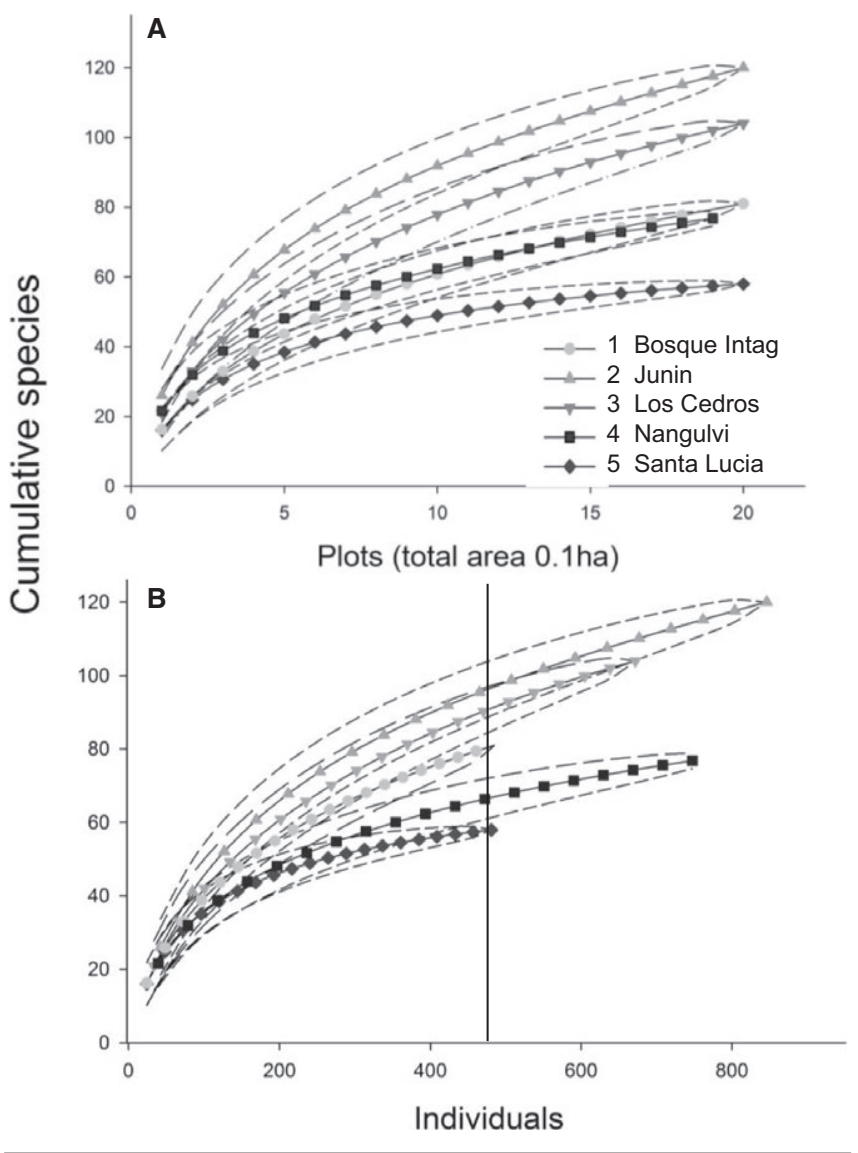

FIGURE 2. Tree species richness in primary cloud forest reserves. Metrics are rarefaction, the Chao estimator, and number of species encountered. Reserves are arranged by size (smallest to largest) and are numbered alphabetically: 1 = Bosque Intag, $2=$ Junin, $3=$ Los Cedros, $4=$ Nangulvi, $5=$ Santa Lucia. Error bars represent standard deviation based on 100 randomized runs.

Nineteen of the 302 species we found were classified as globally endangered or threatened, and eight were near threatened (IUCN 2013). Of these, twelve species were only found in one reserve, six were found in only two, and only one was found in more than two reserves (Table 2).

ENVIRONMENTAL VARIABILITY ACROSS RESERVES.-The similarity in species composition between reserves did not appear to relate to the distance between them, nor to the size of the reserve. The reserves that were the most similar to one another, with an estimated 73 shared-species and a Chao-Jaccard similarity index of 0.53 , were the largest (Los Cedros) and smallest (Nangulvi) (Table 1, Table 3).

In our ordinations, tree communities within each reserve tended to group together. Although reserves that were closer to one another did not generally share more species (Table 3A, Fig. 1), the location (latitude and longitude) of transects did explain some of the variation in tree species composition. The first axis in the NMDS ordination was correlated with longitude $(r=0.668)$, site accessibility, and soil characteristics (Fig. S2) associated with disturbed soils (Bautista-Cruz \& Castillo 2005) - higher 
TABLE 3. Number of shared taxa and similarity index between primary forest reserves by (A) species, (B) genera, and (C) families. The upper diagonal shows the actual number of shared taxa with the Chao-estimated number of shared taxa in parentheses. (B) The lower diagonal shows the similarity index (Chao-Jaccard estimator). Numbers in the rows and columns refer to reserve site numbers, as shown in Fig. 1. Grey areas indicate data for the same reserve.

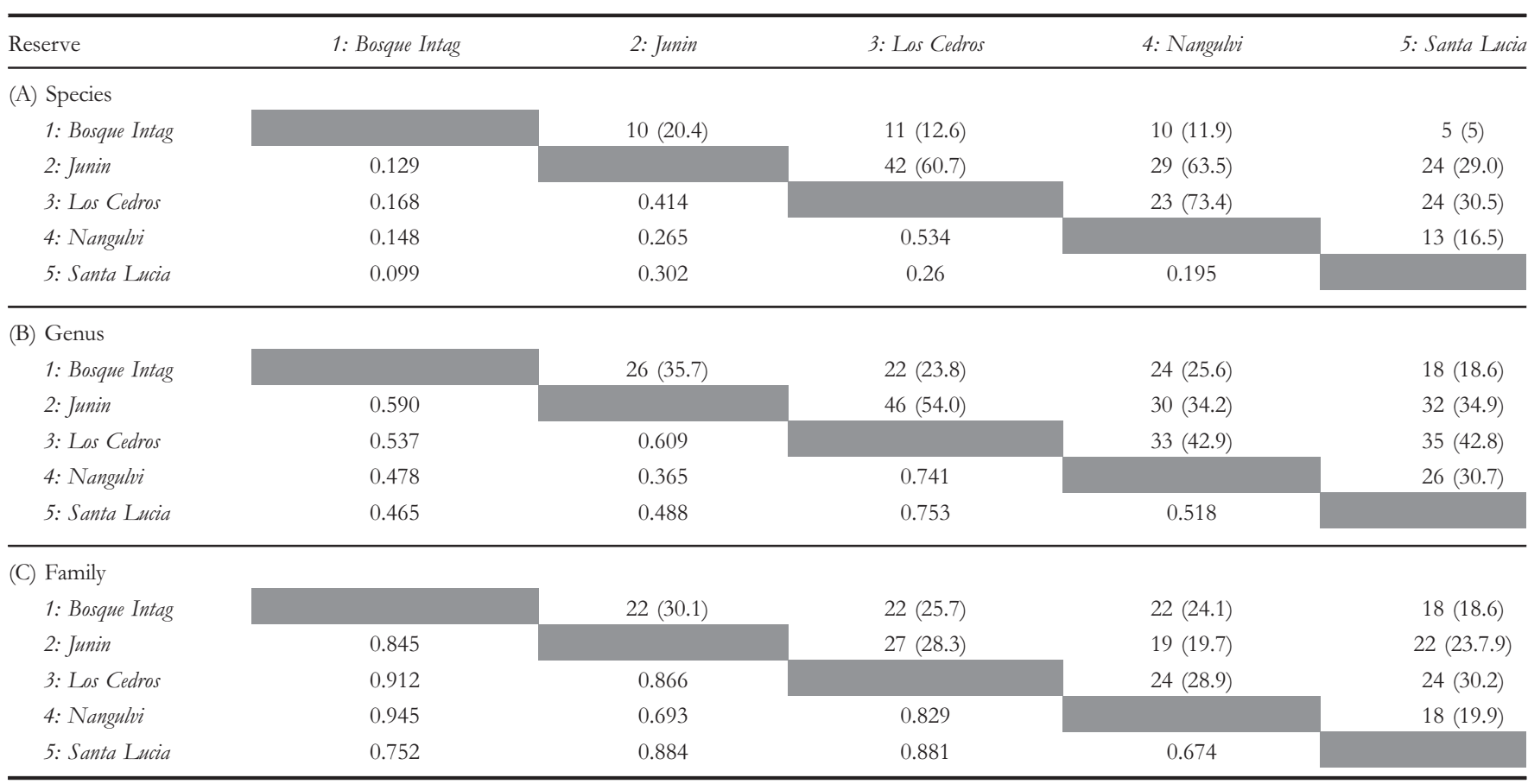

$\mathrm{pH}(r=0.588)$, bulk density $(r=0.425)$, and exchangeable bases $(r=0.633)$. The most eastern reserves scored higher than the western reserves along this axis (Fig. S2). The second axis was positively correlated with latitude $(r=0.698)$, and negatively with soil phosphorus $(r=-0.729)$ and nitrogen $(r=-0.516)$ (Fig. S2).

We examined spatial arrangement and other environmental variables using RDA, which supported the results of the NMDS: (1) the transects in each reserve grouped tightly (i.e., were more similar within reserves); (2) the same reserves came out as most similar to one another (Junin and Santa Lucia, Los Cedros and Nangulvi, with Bosque Intag the most distinct); (3) three groups of species tended to correlate highly with one another; and (4) site accessibility and several soil characteristics correlated with one another and the first axis, separating more accessible sites from more remote ones (Fig. S3). A model of variance partitioning between environmental and spatial variables explained 47 percent of the variation in tree composition. Of this, environmental variables explained 45 percent, and geographic coordinates explained 21 percent. Thus, 19 percent of the variation explained by environmental variables was spatially structured, and space alone explained only two percent. Although it is interesting that the high turnover in tree species composition was somewhat related to environmental and spatial variables, it is important to acknowledge that we did not have sufficient sample size to test the statistical significance of environmental factors or geographic distance on tree community composition.

The area we sampled is common to many peer-reviewed tropical tree studies, including several recent studies in cloud forests and the Gentry database (Phillips et al. 2003) to compare species richness between different forests (Gentry 1988, Mesquita et al. 2001, Norden et al. 2009, Williams-Linera et al. 2013, Williamson et al. 2014, Tello et al. 2015, Wilson and Rhemtulla. However, to account for potential undersampling in these very diverse environments, we used rarefaction to derive estimates of species richness, as well as richness estimators that consider rare species. All estimations produced consistent results across forest types, and in only one forest (with an exceptionally high number of rare species) did the Chao estimator produced $a>20$ percent increase in species richness, the threshold above which may indicate problematic undersampling (Herzog et al. 2002). We also used two ordination measures, one that accounts for undersampling (NMDS, using the Chao-Jaccard) and one that does not (RDA); both produced similar results in terms of differentiation between sites. There are also clear differences in the distribution of the most abundant species in each forest (Table 2), a measure that is less sensitive to undersampling than when rare species are included. Multiple estimates thus reveal similar patterns in species distributions between reserves.

\section{DISCUSSION}

Our study showed that tree communities in Andean cloud forests vary markedly over a small area: ridgetop forest reserves as close as $10 \mathrm{~km}$ apart shared as few as 10 percent of tree species, had different common species, and contained a high percentage of unique trees. Variability in species composition was higher 
between reserves than within them and did not appear to be related to their spatial proximity. Together, the results show that each forest reserve contributes significantly to conserving tree species richness at the landscape scale.

Cloud forest patches hold Unique COMbinations of tree SPECIES.-The conservation value of small forest patches has been debated for decades (Schelhas 1996). Small patches often contain only a subset of the forest species found in intact primary forests and are more vulnerable to disturbance (Turner \& Corlett 1996, Laurence et al. 2006, Saura et al. 2014). But they can still play a key conservation role by maintaining landscape connectivity, gene flow, and ecological memory; serving as seeds sources; and providing habitat. These functions are especially important in heavily cleared landscapes, where they may be the last remnants of primary forest (Kattan et al. 1996, 2004, Holl 1999, Holl et al. 2000, WilliamsLinera et al. 2013). Our study shows that even small patches serve as important reservoirs of tree species in an Andean landscape.

Our results show that ridgetop tree communities at similar elevations are distinct from one another even over relatively short distances-within an area of $875 \mathrm{~km}^{2}$, we found only one tree species common to all five reserves, and even the 'common' species in each reserve were remarkably different. Our work supports research revealing similar patterns in epiphytes, birds, butterflies, and other organisms in the Andes (Gentry 1992, Fjeldså et al. 1999, Brehm et al. 2008, Bruijnzeel et al. 2010, Herzog \& Kattan 2011, Jost 2013). Endemic orchids in the eastern Andes were found on some mountaintops but absent from others only a few kilometers away (Jost 2013), and forests on Centinela, a cloud-forest covered ridge only $100 \mathrm{~km}$ southwest of Intag and approximately $500 \mathrm{~m}$ lower in elevation, contained an estimated 90 species of epiphytes absent from neighboring ridges prior to being cleared in the 1990s (Dodson \& Gentry 1991),

At our sites, the relatively high species turnover-as compared to the genera and family level turnover-corresponds with Gentry's hypothesis of 'explosive speciation'. Based in part on his extensive studies that found high levels of endemism on Centinela, Gentry posited that high species diversity in the Andes is attributed to relatively recent speciation (Gentry 1989) driven by current and historical environmental heterogeneity, dispersal limitation, and biogeographical change. Speciation processes operate on different scales: ultrafine niche partitioning and larger microgeographic differences (e.g., slope orientation and associated microclimates) interact with the historically dynamic landscapes of the Andes, which, divided by mountain ridges, local rainshadows, and frequent landslides, is hypothesized to cause founder effects through genetic drift (Gentry 1989). Because this explosive speciation is relatively recent (and still actively occurring), it would be expected to produce large numbers of species within the same genus; thus, high congener turnover in Andean landscapes is indicative of these processes.

Non-Andean cloud forests also have high tree species turnover. In Veracruz, Mexico, tree communities in cloud forests at similar elevations (1850 to 1950 masl) to reserves in our study showed Chao-Jaccard similarity estimates comparable to ours
$(0.16,0.18$, and 0.40 for 0.1 ha sites that were 28,21 , and $8 \mathrm{~km}$ apart, respectively) (Williams-Linera et al. 2013) (Table 3). Two Guianan montane cloud forests $(2550-2650 \mathrm{~m}$ asl $30 \mathrm{~km}$ apart shared only 38 percent of their tree species (Hetsch \& Hoheisel 1976). In contrast, Neotropical lowland forests tend to be more similar across landscapes. In the Amazon, sites up to $100 \mathrm{~km}$ apart shared 30 to 40 percent of tree species (Condit et al. 2002, Fine \& Kembel 2011). In Oaxaca, lowland forest fragments separated by 15 to $100 \mathrm{~km}$ had Jaccard shared species indices of 0.11 and 0.57 , compared to the greater dissimilarity of 0.03 and 0.175 over 10 to $35 \mathrm{~km}$ at our sites (Gordon et al. 2004). The difference in species distributions between montane and lowland forests indicates that different mechanisms drive species distributions, with topography playing an especially important role in the mountains (Gentry 1988, Young et al. 1995, Condit et al. 2002, Kessler 2002, Knapp 2002, Küper et al. 2004). Thus, montane and lowland forests require distinct and specific strategies to manage and maintain biodiversity on the landscape scale (Gentry 1992).

Correlates of VAriation.-Elevation is the main driver of species turnover in cloud forests (Givnish 1998, Watkins et al. 2006, Jankowski et al. 2013, Williams-Linera et al. 2013, Lippok et al. 2014). But limiting our study to a narrow elevational range, no one factor was best correlated with variation. In the Intag region, forests at the same elevation are often isolated from one another by ridges, which act as barriers limiting plant seed dispersal and dispersers (Graham et al. 2010) thereby creating biotic isolation similar to islands (MacArthur 1967, Wilson 1992). This likely explains, in part, why our reserves are so different from one another: All except two are separated from each other by a ridge at least $400 \mathrm{~m}$ high (Fig. 1). The two reserves not separated by a ridge-Santa Lucia and Junin - group most closely in the ordinations despite being relatively far apart $(22 \mathrm{~km})$ and separated by a deep, $(700 \mathrm{~m}$ asl) wide valley. This anecdotal evidence suggests that studying how ridges and valleys affect seed dispersion by wind and animals is an important research question for understanding species distributions in Andean forests (Ramirez-Villegas et al. 2014).

The spatial arrangement of the reserves alone did not appear to explain much variation in tree communities - almost all variability was correlated with changes in environmental variables. Distance between reserves was not a good proxy for the similarity (or distinctiveness) of the species they support (Aubad et al. 2008). Thus, conservation decisions based on the assumption that spatially closer sites are more similar, a common assumption for lowland forests (Condit et al. 2002), would not necessarily maximize landscape diversity in cloud forest regions.

CONSERVING BIODIVERSITY IN ANDEAN LANDSCAPES.-The highest conservation priority is often assigned to areas that are large and intact; critical for connectivity; threatened with rapid land conversion; or which contain high levels of rare or threatened habitats, species richness, or endemic or endangered species. Our results suggest that conservation schemes prioritizing only local species richness or forest patch area — often the default metrics used to prioritize conservation efforts (Prendergast et al. 1999, Margules \& 
Pressey 2000, Raberg \& Rudel 2007) — are not adequate in fragmented cloud forest landscapes. Because they are so heterogeneous, cloud forest requires conserving patches across the landscape.

Large, intact forest areas undoubtedly have enormous conservation value. We found that larger (1500 to $6800 \mathrm{ha}$ ), less accessible reserves generally contained more species than smaller (30 to $500 \mathrm{ha}$ ), more accessible ones (MacArthur 1967, Bierregaard et al. 1992). Because we surveyed young trees along with older ones, this may reflect changes in the abundance of seed dispersers, soil conditions, or other impacts of past disturbance that can affect tree recruitment (Holl 1999, Cordeiro \& Howe 2003). Overall, together the two largest reserves contained 182 or 61 percent of tree species and thus have significant conservation value. These two reserves, Los Cedros and Junin, hold large areas of remarkably intact cloud forest conserved by long-term, dedicated efforts of collaborations between expatriates, local residents, and activist community groups (Peck et al. 2011, DECOIN 2018, Los Cedros 2018) - their value should not be underestimated. Large areas of forest are also essential to conserve migratory species, plants, and animals sensitive to edge effects or requiring large ranges, and to accommodate range shifts predicted to accompany the rapidly changing climate (Kattan et al. 1994, Kessler et al. 2001, Gibson et al. 2013, Lippok et al. 2014).

But the smaller reserves supported an additional 118, or 39 percent, of tree species not found in the larger reserves - even the smallest (30 ha) housed 78 species, 35 of which were unique to that reserve. Every reserve also contributed to conserving rare, endemic, and endangered species across the landscape (Toledo-Aceves et al. 2014) - in each we found threatened species absent from others, and 12 of the 19 threatened or endangered tree species we encountered were found in only one of the five reserves. Because trees are long lived, there could be an extinction debt, where the impacts of fragmentation may take decades to fully manifest (Vellend et al. 2006, Gibson et al. 2013). But even so, small cloud forest reserves are critical to maintain landscape-level tree diversity in Andean cloud forests (Kelly et al. 1994, Toledo-Aceves et al. 2014).

Remnant old growth or primary forests are also important for restoration efforts. Ecological restoration is increasingly partnered with conservation to protect, connect, and expand existing forests (Young \& Lipton 2006) often by attempting to bring back historical species compositions (SER 2004), which requires both knowledge of what species comprised past ecosystems and access to local seed sources. Because cloud forest tree communities vary so much over small spatial scales, local remnant forests are extremely important. Fortunately, unlike flat lowland areas where almost all the land in a given area might be cleared and cultivated, in the mountains small patches of forest often remain on private land in especially steep areas, or along streams and gullies (Keating 1997, Young 2009). The challenge is to create policies and practices to conserve and expand them.

\section{CONCLUSION}

The previously unstudied upper cloud forests in the Intag Valley show exceptional biodiversity and change over small distances at similar elevations. Comparative studies, like this one, are important to characterize and develop conservation strategies for montane tree species. We found that each cloud forest reserve was characterized by different combinations of both common and rare tree species. Conserving tree biodiversity in cloud forests thus requires that we conserve large areas of intact forests where they exist, but also provide incentives and resources for local landholders and communities to conserve and restore remaining forest patches, especially where they represent the last vestiges of primary forest.

\section{ACKNOWLEDGMENTS}

Situated knowledge specific to mountain environments played a key role in developing this study (Nazarea 2006). Hiking through our forests, Ecuadorian botanist Miguel Angel Chinchero, who has over ten years experience identifying cloud forest trees and recognizes most species on sight, noticed that the dominant tree communities differed markedly between forest sites. Distant sites, in some cases, were more similar than neighboring ones. $\mathrm{He}$ made these observations throughout the forest reserves, beyond the area sampled using transects, and his observations were the inspiration for more extensive study. The data we collected and our analyses here correlate highly with his initial observations in the field. We wish to thank botanists Miguel Angel Chinchero, Jenny Elizabeth Correa, Gabriela Cruz, and Carlos Morales for their help in the field and laboratory; Jake Brennan for his assistance with soil sampling, interviews, constructive comments on this article, and beautiful photography; Miriam Harder, Silvana Bolanos, Alonzo Andrengo, and Carmen Navarette for their assistance with interviews; Carlos Zorilla of DECOIN, Joseph de Coux of the Los Cedros Reserve, and Ana Mariscal of Fundacion Cambugan for their help with fieldwork logistics and information; to Gabriela Barragán for translating the Spanish abstract; and Oliver Coomes, Sylvia Wood, Ignacia Holmes, Aerin Jacob, and Robin Chazdon for their insightful comments on study design, results, and earlier versions of this article. This study was funded by the International Development and Research Centre (IDRC), the National Science and Engineering Council of Canada (NSERC), the Fonds de Recherché Nature et Technologies Quebec (FQRNT), and the Theo Hills foundation.

\section{DATA AVAILABILITY}

Data available from the Dryad Digital Repository: https://doi. org/10.5061/dryad.3nr41 (Wilson \& Rhemtulla 2018).

\section{SUPPORTING INFORMATION}

Additional Supporting Information may be found online in the supporting information tab for this article:

TABLE S1. Factors considered in multivariate analyses of primary forest tree communities.

FIGURE S1. Species density and richness in primary cloud forest reserves. 
FIGURE S2. Non-metric multidimensional scaling ordination for primary forests.

FIGURE S3. Redundancy analysis model for primary forests explaining 50 percent of the variation in the data.

\section{LITERATURE CITED}

Aiba, S. I., And K. KitaYAma. 1999. Structure, composition and species diversity in an altitude-substrate matrix of rain forest tree communities on Mount Kinabalu, Borneo. Plant Ecol. 140: 139-157.

Armenteras, D., F. Gast, and H. Villareal. 2003. Andean forest fragmentation and the representativeness of protected natural areas in the eastern Andes, Colombia. Biol. Cons. 113: 245-256.

Aubad, J., P. Aragón, M. Á. Olalla-Tárraga, and M. Á. Rodríguez. 2008. Illegal logging, landscape structure and the variation of tree species richness across North Andean forest remnants. For. Ecol. Manage. 255: 1892-1899.

Bach, K., and S. Robbert Gradstein. 2011. A comparison of six methods to detect altitudinal belts of vegetation in tropical mountains. Ecotropica. 17: $1-13$.

Bautista-Cruz, A., and R. F. D. Castillo. 2005. Soil changes during secondary succession in a tropical montane Cloud Forest Area. Soil Sci. Soc. Am. J. 69: 906-914.

Bierregaard Jr, R. O., T. E. Lovejoy, V. Kapos, A. A. dos Santos, and R. W. Hutchings. 1992. The biological dynamics of tropical rainforest fragments. Bioscience 85: 9-866.

Brehm, G., J. Homeier, K. Fiedler, I. Kottke, J. Illig, N. Nöske, F. Werner, AND S. BReCKLE. 2008. Mountain rain forests in southern Ecuador as a hotspot of biodiversity-limited knowledge and diverging patterns. In E. Beck (Ed.). Gradients in a tropical mountain ecosystem of Ecuador, pp. 15-23. Springer-Verlag, Berlin, Germany.

Brooks, T. M., R. A. Mittermeier, G. A. da Fonseca, J. Gerlach, M. Hoffmann, J. F. Lamoreux, C. G. Mittermeier, J. D. Pilgrim, and A. S. RODRIGUES. 2006. Global biodiversity conservation priorities. Science 313: 58-61.

Bruijnzeel, L. A. 2004. Hydrological functions of tropical forests: not seeing the soil for the trees? Agr. Ecosyst. Environ. 104: $185-228$.

Bruijnzeel, L. A., F. N. Scatena, and L. S. Hamilton. 2010. Tropical montane cloud forests: science for conservation and management. Cambridge University Press, Cambridge, UK.

Cardelús, C. L., R. K. Colwell, and J. E. Watkins. 2006. Vascular epiphyte distribution patterns: explaining the mid-elevation richness peak. J. Ecol. 94: 144-156.

CHAO, A.. 1984. Nonparametric estimation of the number of classes in a population. Scand. J. Stat. 11: 265-270.

Chao, A., R. L. Chazdon, R. K. Colwell, and T. J. Shen. 2005. A new statistical approach for assessing similarity of species composition with incidence and abundance data. Ecol. Lett. 8: 148-159.

Chazdon, R. L., R. K. Colwell, J. S. Denslow, and M. R. Guariguata. 1998. Statistical methods for estimating species richness of woody regeneration in primary and secondary rain forests of northeastern Costa Rica. In F. Dallmeier, and J. A. Comiskey (Eds.). Forest biodiversity research, monitoring and modeling: conceptual background and old world case studies. Man and the Biosphere Series Vol. 20, pp. 285-309.

Chen, Y. C., W.-H. Hwang, A. Chao, and C.-Y. Kuo. 1995. Estimating the number of common species. Analysis of the number of common bird species in Ke-Yar Stream and Chung-Kang Stream. J. Chin. Stat. Assoc. 33: 373-393.

CoLWELL, R. K. 2009. Estimates: Statistical estimation of species richness and shared species from samples. Version 8.2 and earlier. User's Guide and application. Published at: http://purl.oclc.org/estimates.
Condit, R., N. Pitman, E. G. Leigh, J. Chave, J. Terborgh, R. B. Foster, P. Núnez, S. Aguilar, R. Valencia, and G. Villa. 2002. Beta-diversity in tropical forest trees. Science 295: 666-669.

Cordeiro, N. J., And H. F. Howe. 2003. Forest fragmentation severs mutualism between seed dispersers and an endemic African tree. Proc. Natl Acad. Sci. USA 100: 14052-14056.

DiAmond, J. M. 1975. The island dilemma: lessons of modern biogeographic studies for the design of natural reserves. Biol. Cons. 7: 129-146.

Dodson, C. H., and A. H. Gentry. 1991. Biological extinction in western Ecuador. Ann. Mo. Bot. Gard. 78: 273-295.

Echeverría, C., L. Cayuela, R. Manson, D. Coomes, A. Lara, J. ReyBenayas, and A. Newton. 2007. Spatial and temporal patterns of forest loss and fragmentation in Mexico and Chile. In A. C. Newton (Ed.) Biodiversity loss and conservation in fragmented forest landscapes. The forests of montane Mexico and temperate South America, pp. 14-42. CABI, Wallingford, Oxfordshire, UK.

Fine, P., And S. Kembel. 2011. Phylogenetic community structure and phylogenetic turnover across space and edaphic gradients in western Amazonian tree communities. Ecography 34: 552-565.

FJeldså, J., E. Lambin, and B. Mertens. 1999. Correlation between endemism and local ecoclimatic stability documented by comparing Andean bird distributions and remotely sensed land surface data. Ecography 22: 63-78.

Freiberg, M., And E. Freiberg. 2000. Epiphyte diversity and biomass in the canopy of lowland and montane forests in Ecuador. J. Trop. Ecol. 16: 673-688.

GENTRY, A. H.. 1988. Changes in plant community diversity and floristic composition on environmental and geographical gradients. Ann. Mo. Bot. Gard. 75: 1-34.

Gentry, A. H. 1989. Speciation in tropical forests. In I. C. Holm-Nielsen et al. (Eds). Tropical forests: botanical dynamics, speciation, and diversity, pp. 113-134. Botanical Institute, Aarhus University, Academic Press Limited, London.

Gentry, A. 1992. Diversity and floristic composition of Andean forests of Peru and adjacent countries: implications for their conservation. Memorias del Museo de Historia Natural. UNMSM (Lima) 21: 1129.

Gentry, A. H., S. Churchill, H. Balslev, E. Forero, and J. Luteyn. 1995. Patterns of diversity and floristic composition in Neotropical montane forests. Biodiversity and conservation of Neotropical montane forests. Proceedings of a symposium, New York Botanical Garden, 21-26 June 1993., pp. 103-126. New York Botanical Garden.

Gibson, L., A. J. Lynam, C. J. A. Bradshaw, F. He, D. P. Bickford, D. S. WoodrufF, S. Bumrungsri, and W. F. Laurance. 2013. Near-complete extinction of native small mammal fauna 25 years after forest fragmentation. Science 341: 1508-1510.

Givnish, T. J. 1998. Altitudinal gradients in tropical forest composition, structure, and diversity in the Sierra de Manantlán. J. Ecol. 86: 9991020.

Gordon, J. E., W. D. Hawthorne, A. Reyes-Garcia, G. Sandoval, and A. J. BarRANCE. 2004. Assessing landscapes: a case study of tree and shrub diversity in the seasonally dry tropical forests of Oaxaca, Mexico and southern Honduras. Biol. Cons. 117: 429-442.

Graham, C. H., N. Silva, and J. Velásquez-Tibatá. 2010. Evaluating the potential causes of range limits of birds of the Colombian Andes. J. Biogeogr. 37: 1863-1875.

Haber, W. A. 2000. Plants and vegetation. In N. M. Nadkarni, and N. T. Wheelwright (Eds.). Monteverde: ecology and conservation of a tropical cloud forest, pp. 39-70. Oxford University Press, Oxford, UK.

Hansen, M. C., P. V. Potapov, R. Moore, M. Hancher, S. A. Turubanova, A. Tyukavina, D. Thau, S. V. Stehman, S. J. Goetz, T. R. Loveland, A. Kommareddy, A. Egorov, L. Chini, C. O. Justice, and J. R. G. TownsHend. 2013. High-resolution global maps of 21st-century forest cover change. Science 342: 850-853. 
Herzog, S. K., M. Kessler, and T. M. Cahill. 2002. Estimating species richness of Neotropical bird communities from rapid assessment data. Auk. 119: 749-769.

Herzog, S. K., and G. H. Kattan. 2011. Patterns of Diversity and Endemism in the Birds of the Tropical Andes. In R. Martínez, P. M. Jørgensen, and H. Tiessen (Eds.). Climate change and biodiversity in the tropical Andes, pp. 245-259. McArthur Foundation, Inter-American Institute for Global Change Research (IAI) and Scientific Committee on Problems of the Environment (SCOPE), Paris, France.

Hetsch, W., And H. HoheIsel. 1976. Standorts- und vegetations- gliederung in einem tropischen nebelwald. Allg. Forst Jagdz 147: 200-209.

HolL, K. D. 1999. Factors limiting tropical rain forest regeneration in abandoned pasture: seed rain, seed germination, microclimate, and soil. Biotropica 31: 229-242.

Holl, K. D., M. E. Loik, E. H. Lin, And I. A. Samuets. 2000. Tropical montane forest restoration in Costa Rica: overcoming barriers to dispersal and establishment. Restor. Ecol. 8: 339-349.

Howard, R. A. 1968. The ecology of an elfin forest in Puerto Rico, 1. Introduction and composition studies. J. Arnold. Arbor. 49: 381-418.

IUCN. 2013. The IUCN Red List of Threatened Species Version 2013.2. Retrieved from

Jankowski, J. E., C. L. Merkord, W. F. Rios, K. G. Cabrera, N. S. Revilla, and M. R. Silman. 2013. The relationship of tropical bird communities to tree species composition and vegetation structure along an Andean elevational gradient. J. Biogeogr. 40: 950-962.

Jokisch, B. D., AND B. M. Lair. 2002. One last stand? Forests and change on Ecuador's eastern cordillera. Geograph. Rev. 92: 135-156.

Jost, L. 2013. Biogeography of the Pastaza watershed. Retrieved July 2013 from: http://www.loujost.com/Biogeography of the Pastaza Watershed/Pastaza.htm

Kattan, G. H., H. Alvarez-Lopez, and M. Giraldo. 1994. Forest fragmentation and bird extinctions: San Antonio eighty years later. Conserv. Biol. 8: 138-146.

Kattan, G. H., H. Alvarez-Lopez, J. Schelhas, and R. Greennerg. 1996. Preservation and management of biodiversity in fragmented landscapes in the Colombian Andes. In J. Schelhas, and R. Greenberg (Eds.). Forest patches in tropical landscapes, pp. 3-18. Island Press, Washington, District of Columbia.

Kattan, G. H., P. Franco, V. Rojas, and G. N. Morales. 2004. Biological diversification in a complex region: a spatial analysis of faunistic diversity and biogeography of the Andes of Colombia. J. Biogeogr. 31: 1829-1839.

KeatiNG, P. L. 1997. Mapping vegetation and anthropogenic disturbances in southern Ecuador with remote sensing techniques: implications for park management. Yearbook. Conference of Latin Americanist Geographers: $77-90$.

Kelly, D. L., E. V. J. Tanner, E. M. Nic Lughadha, and V. Kapos. 1994. Floristics and biogeography of a rain forest in the Venezuelan Andes. J. Biogeogr. 21: 421-440.

KessLer, M. 2002. The elevational gradient of Andean plant endemism: varying influences of taxon-specific traits and topography at different taxonomic levels. J. Biogeogr. 29: 1159-1165.

Kessler, M., S. K. Herzog, J. FjeldsÅ, and K. Bach. 2001. Species richness and endemism of plant and bird communities along two gradients of elevation, humidity and land use in the Bolivian Andes. Divers. Distrib. 7: 61-77.

KNAPP, S. 2002. Assessing patterns of plant endemism in Neotropical uplands. Bot. Rev. 68: 22-37.

Küper, W., H. Kreft, J. Nieder, N. Köster, and W. Barthlott. 2004. Large-scale diversity patterns of vascular epiphytes in Neotropical montane rain forests. J. Biogeogr. 31: 1477-1487.

Laurance, W. F., E. M. N. Henrique, S. G. Laurance, A. C. Andrade, P. M. Fearnside, J. E. L. Ribeiro, and R. L. Capretz. 2006. Rain forest fragmentation and the proliferation of successional trees. Ecology. 87: $469-482$.
Legendre, P., D. Borcard, and P. R. Peres-Neto. 2005. Analyzing beta diversity: partitioning the spatial variation of community composition data. Ecol. Monogr. 75: 435-450.

Lemmon, P. E. 1957. A new instrument for measuring forest overstory density. J. Forest. 55: 667-668.

Lindenmayer, D. B., J. F. Frankinn, and J. Fischer. 2006. General management principles and a checklist of strategies to guide forest biodiversity conservation. Biol. Cons. 131: 433-445.

Lippok, D., S. G. Beck, D. Renison, I. Hensen, A. E. Apaza, and M. SchleUNING. 2014. Topography and edge effects are more important than elevation as drivers of vegetation patterns in a neotropical montane forest. J. Veg. Sci. 25: 724-733.

Lomolino, M. A. R. K. 2001. Elevation gradients of species-density: historical and prospective views. Glob. Ecol. Biogeograp. 10: 3-13.

MacArthur, R. H. 1967. The theory of island biogeography. Princeton University Press, Princeton, New Jersey.

Margules, C. R., and R. L. Pressey. 2000. Systematic conservation planning. Nature 405: 243-253.

McCune, B., AND M. J. MefFord. 2011. PC-ORD for windows. Multivariate analysis of ecological data. Version 6.0.

Mesquita, R., K. Ickes, G. Ganade, and G. Williamson. 2001. Alternative successional pathways in the Amazon Basin. J. Ecol. 89: 528537.

Mitchell, A. T., M. L. Clark, H. R. Grau, D. López-Carr, M. A. Levy, D. Redo, M. Bonilla-Moheno, G. Riner, J. AndradeNúÑezmaría, And M. Muñiz. 2013. Deforestation and reforestation of Latin America and the Caribbean (2001-2010). Biotropica. 45: 262-271.

Mittermeier, R. A., N. Myers, C. G. Mittermeier, and P. Robles Gil. 1999. Hotspots: Earth's biologically richest and most endangered terrestrial ecoregions. CEMEX, SA, Agrupación Sierra Madre, SC.

Muluigan, M. 2010. Modeling the tropics-wide extent and distribution of cloud forest and cloud forest loss, with implications for conservation priority. In L. A. Bruijnzeel, F. N. Scatena, and L. S. Hamilton (Eds.). Tropical montane cloud forests: science for conservation and management, International Hydrology Series, 14 pp. Cambridge University Press, Cambridge, UK.

Myers, N., R. A. Mittermeier, C. G. Mittermeier, G. A. Da Fonseca, and J. KeNT. 2000. Biodiversity hotspots for conservation priorities. Nature 403: 853-858.

MysteR, R. W. 2017. Gradient (elevation) vs. disturbance (agriculture) effects on primary cloud forest in Ecuador: floristics and physical structure. NZ J. Forest. Sci. 47: 3.

NAZAREA, V. D. 2006. Local knowledge and memory in biodiversity conservation. Annu. Rev. Anthropol. 35: 317-335.

Norden, N., R. L. Chazdon, A. Chao, Y. H. Jiang, and B. Vílchez-AlvarADO. 2009. Resilience of tropical rain forests: tree community reassembly in secondary forests. Ecol. Lett. 12: 385-394.

Noss, R. F. 1983. A regional landscape approach to maintain diversity. Bioscience 33: 700-706.

OKSANEN, J. 2011. Multivariate analysis of ecological communities in R: vegan tutorial. $\mathrm{R}$ package version 1 .

Ovaskainen, O. 2002. Long-term persistence of species and the SLOSS problem. J. Theoret. Biol. 218: 419-433.

Patterson, B. D. 1987. The principle of nested subsets and its implications for biological conservation. Conserv. Biol. 1: 323-334.

Phillips, O. L., R. V. Martínez, P. N. Vargas, A. L. Monteagudo, M. E. C. Zans, W. G. Sánchez, A. P. Cruz, M. Timaná, M. Y. Halla, and S. Rose. 2003. Efficient plot-based floristic assessment of tropical forests. J. Trop. Ecol. 19: 629-645.

Pickett, S. T. A., And J. N. Thompson. 1978. Patch dynamics and the design of nature reserves. Biol. Cons. 13: 27-37.

Prendergast, J. R., R. M. Quinn, and J. H. Lawton. 1999. The gaps between theory and practice in selecting nature reserves. Conserv. Biol. 13: 484-492. 
RABERG, L. M., AND T. K. RuDEL. 2007. Where are the sustainable forestry projects?: A geography of NGO interventions in Ecuador. Appl. Geogr. 27: 131-149.

Ramirez-Villeggas, J., F. Cuesta, C. Devenish, M. Peralvo, A. Jarvis, and C. A. Arnillas. 2014. Using species distributions models for designing conservation strategies of Tropical Andean biodiversity under climate change. J. Nat. Conserv. 22: 391-404.

Salazar, L., J. Homeier, M. Kessler, S. Abrahamczyk, M. Lehnert, T. KrÖMER, AND J. KLuge. 2013. Diversity patterns of ferns along elevational gradients in Andean tropical forests. Plant Ecol. Divers 8: $1-12$.

SÁnchez-GonzÁlez, A., And L. López-Mata. 2005. Plant species richness and diversity along an altitudinal gradient in the Sierra Nevada, Mexico. Divers. Distrib. 11(6): 567-575.

Saura, S., Ö. Bodin, and F. Marie-Josée. 2014. Editor's choice: Stepping stones are crucial for species' long-distance dispersal and range expansion through habitat networks. J. Appl. Ecol. 51: 171182.

SARMiento, F. O.. 1995. Naming and knowing an Ecuadorian landscape: a case-study of the Maquipucuna Reserve. George Wright Forum 12: $15-22$.

Sarmiento, F. O. 2002. Anthropogenic change in the landscapes of highland Ecuador. Geogr. Rev. 92: 213-234.

Scatena, F., L. Brujunzeel, P. Bubb, And S. Das. 2010. Setting the stage. In L. A. Bruijnzeel, F. N. Scatena and L. S. Hamilton. (Eds.). Tropical montane cloud forests: science for conservation and management, pp. 112. Cambridge University Press, Cambridge.

SCHelHas, J. 1996. Forest patches in tropical landscapes. Island Press, Washington, District of Columbia.

Schiwartzman, S., A. Moreira, and D. Nepstad. 2000. Rethinking tropical forest conservation: perils in parks. Conserv. Biol. 14: 1351-1357.

SER. 2004. The SER International Primer on Ecological Restoration. http:// www.ser.org \& Tucson: Society for Ecological Restoration International.

SHI, J. P., AND H. Zhu. 2009. Tree species composition and diversity of tropical mountain cloud forest in the Yunnan, southwestern China. Ecol. Res. 24: 83-92.

Simberloff, D., And L. G. Abele. 1982. Refuge design and island biogeographic theory: effects of fragmentation. Am. Nat. 120: 41-50.

Sugden, A. M. 1982. The vegetation of the Serrania de Macuira, Guajira, Colombia: a contrast of arid lowlands and an isolated cloud forest. J. Arnold. Arbor. 63: 1-30.

Tello, J., J. Myers, M. Macía, A. Fuentes, L. Cayola, G. Arellano, et al. 2015. Elevational Gradients in $\beta$-Diversity Reflect Variation in the Strength of Local Community Assembly Mechanisms across Spatial Scales. PLoS ONE 10: e0121458.

Tjørve, E. 2010. How to resolve the SLOSS debate: Lessons from speciesdiversity models. J. Theoret. Biol. 264: 604-612.
Toledo-Aceves, T., J. G. García-Franco, G. Williams-Linera, K. MacMillan, and C. Gallardo-Hernández. 2014. Significance of remnant cloud forest fragments as reservoirs of tree and epiphytic bromeliad diversity. Trop. Conserv. Sci. 7: 230-243.

Turner, I. M., AND R. T. Corlett. 1996. The conservation value of small, isolated fragments of lowland tropical rain forest. Trends Ecol. Evol. 11: $330-333$.

Vellend, M., K. Verheyen, H. Jacquemyn, A. Kolb, H. V. Calster, G. Peterken, and M. Hermy. 2006. Extinction debt of forest plants persists for more than a century following habitat fragmentation. Ecology 87: $542-548$.

Watkins, J. E., C. Cardelús, and R. Colwell. 2006. Vascular epiphyte distribution patterns: explaining the mid-elevation richness peak. J. Ecol. 94: 144-156.

WiLliams-Linera, G. 2002. Tree species richness complementarity, disturbance and fragmentation in a Mexican tropical montane cloud forest. Biodivers. Conserv. 11: 1825-1843.

Williams-Linera, G., M. Toledo-Garibaldi, and C. G. Hernandez. 2013. How heterogeneous are the cloud forest communities in the mountains of central Veracruz, Mexico? Plant Ecol. 214: 685-701.

Williamson, G., T. Bentos, J. B. Longworth, and R. Mesquita. 2014. Convergence and divergence in alternative successional pathways in Central Amazonia. Plant Ecol. Divers 7: 1-8.

Wirson, E. O. 1992. The Diversity of Life. Harvard University Press, New York, New York.

WiLSON, S. J. 2015. Replanting a Future: Restoring cloud forests, biodiversity. and rural livelihoods in Andean Landscapes. PhD Dissertation. McGill University.

Wilson, S. J., And J. M. Rhemtulla. 2016. Acceleration and novelty: community restoration speeds recovery and transforms species composition in Andean cloud forest. Ecol. Appl. 26: 203-218.

Witson, S. J., and J. M. Rhemtulla. 2018. Data fzrrom: Small montane cloud forest fragments are important for conserving tree diversity in the Ecuadorian Andes. Dryad Digital Repository. https://doi.org/10. 5061/dryad.3nr41

Young, K. R. 2009. Andean land use and biodiversity: humanized landscapes in a time of change. Ann. Mo. Bot. Gard. 96: 492-507.

Young, K. R., B. León, S. P. Churchill, H. Batslev, E. Forero, and J. L. LutEYn. 1995. Connectivity, social actors, and conservation policies in the central Andes. The case of Peru's montane forest. Biodiversity and conservation of Neotropical montane forests. Proceedings of a symposium, New York Botanical Garden, 21-26 June 1993. New York Botanical Garden: 653-661.

YounG, K. R., AND J. K. Lipton. 2006. Adaptive governance and climate change in the tropical highlands of western South America. Clim. Change. 78: 63-102.

Zador M. (Ed.) Ecosystem profile: Tropical andes biodiversity hotspot. Critical ecosystem partnership fund. 